\title{
From natural to constructed: a proposal to estimate heat accumulation in metropolises
}

\author{
Do natural ao construído: proposta \\ para estimar acúmulo de calor em metrópoles
}

Ruskin Freitas [I] Jaucele Azerêdo [II]

\begin{abstract}
The transformation from a natural environment to a built environment causes the formation of different urban climates, according to urban geometry, materials and activities. The objective of this article is to present a methodology to estimate heat accumulation in urban precincts, according to the influence of ten climatic factors, assessed through values on a scale graduated into five levels: accumulation of negative, null, low, medium and high heat, the latter being able to reach six positive degrees $\left(+6.0^{\circ} \mathrm{C}\right)$ in relation to the value verified in the reference meteorological station. The application of this methodology can support comparisons between metropolises and guide interventions aimed at user satisfaction, the efficiency of the built space and environmental sustainability.
\end{abstract}

Keywords: urbanization; spatial transformations; urban climates; heat accumulation; Recife.

\section{Resumo}

A transformação de um ambiente natural em um ambiente construído ocasiona a formação de diferentes climas urbanos, de acordo com geometria urbana, materiais e atividades. 0 objetivo deste artigo é apresentar uma metodologia para se estimar o acúmulo de calor em recintos urbanos, considerando a influência de dez fatores climáticos, avaliados através de uma escala graduada em cinco níveis: acúmulo de calor negativo, nulo, baixo, médio e alto, podendo chegar a um total de seis graus positivos $\left(+6,0^{\circ} \mathrm{C}\right)$, em relação àquele valor verificado na estação meteorológica de referência. A aplicação dessa metodologia, desenvolvida a partir de pesquisas diversas, poderá embasar comparações entre metrópoles e orientar intervenções que visem à satisfação do usuário, à eficiência dos espaços è à sustentabilidade ambiental.

Palavras-chave: urbanização; climas urbanos; acúmulo de calor; Recife. 


\section{Introduction}

Urbanization is characterized by the replacement of natural elements, such as a permeable ground surface, watercourses and vegetation, by built structures, such as impermeable surfaces, road systems and building volumes. These transformations have been viewed from a variety of different perspectives. The most common is to focus on the increase in population and the pressure increased population density exerts on nature and society. According to data published by the 2017 edition of the World Population Prospects report (United Nations, 2017, p. 1), by mid-2017, the world population stood at around 7.6 billion inhabitants. Of these, 55\% lived in urban areas and it is estimated that, by the middle of the 21st century, this percentage will rise to $68 \%$, representing a further 2.5 billion city-dwellers between 2018 and 2050 (United Nations, 2019, p. 1). The world population of the future will thus be urban.

Pires, Kneib \& Ribeiro (2020, p. 248) state that "the way these new inhabitants are accommodated in the territory has environmental, social and economic ramifications". Alvin, Kato \& Rossin (2015, p. 84), more specifically note that "urban sprawl generates numerous problems with serious consequences for society, such as soil sealing, alterations to the urban drainage system, climate change, and so forth".

The transformation of the natural environment into a built one causes an increase in temperature and, consequently, heat accumulation, the intensity of which depends on the elements, forms, activities and a wide range of other factors associated with the formation of urban climates. In other words, the extent of possible social and spatial transformation will affect changes in the behavior of climatic elements differently in different settings, in general, increasing air temperature, reducing relative air humidity, and changing the direction of winds. It should be stressed that the degree of alteration in climate parameters is directly proportional to the changes brought about by climate change.

Simple comparison between the natural and the built environment or between the rural and the urban fails to take into account such changes. As Oke et al. (2017, p.168) put it, the process "involves... three sets of intertwined factors: thermal properties, moisture availability of moisture, and geometric form". In other words, the absorption, storage and emission of heat depend on both natural and anthropogenic climate factors in such a way that the combination of materials, elements and forms may give rise to widely differing situations. We should also bear in mind the main use for which the urban space is intended, since the type of use (residential, commercial, or industrial) to which a space is put may predispose it to attract certain types of activities and population groups. Each setting should thus be considered in terms of its own specific features.

Stewart \& Oke (2012, p. 1885) conducted an extensive review of various studies of urban climate and came up with a new classification of 17 homogeneous regions called 'urban climate zones', varying from semi-urban to heavily urbanized areas. "We formally define local climate zones as regions of uniform surface cover, structure, material and human activity that span hundreds of meters to several kilometers in horizontal scale," they say. 
However, in practice, such homogeneity is rare in the urban environment, especially in urban metropolises in Brazil, which are typified by environmental diversity, socioeconomic fragmentation, and multiple urban parameters and institutional zones. This gives rise to a juxtaposition of distinct morphological types, which are generally small in scale. These various urban configurations in turn generate different levels of heat accumulation.

Stewart \& Oke's important study (ibid.) characterizes, classifies and compares different locations, and highlights the importance of the association between morphological characteristics and local climate measurements, thereby enabling them to show the inter-related influences of these diverse elements. However, it is important to contextualize and develop these and examine them in greater depth at local level. Almeida (2019, p. 61) notes that "the LCZ [local climate zone] system is generic and incapable of capturing the peculiarities of each and every urban or rural setting. The view of landscape is highly reductionist and, as with all classifications, its descriptive and explanatory power is limited".

Climate studies begin with the observation of climate elements, measuring climate parameters such as air temperature, relative air humidity, precipitation, wind speed, and wind direction. Data relating to these climate features are collected at weather stations, updated practically in real time, and published daily by the National Meteorological Institute - Inmet and the National Institute for Space Research - INPE. These data are generally collected at locations in which conditions approximate to those of the natural environment, with minimal influence of human interventions (a natural ground surface, permeable to sun and wind).

The atmospheric climate, when observed over a long period of time, is used as the basis for climate studies, using time series, normally covering 30 years of observations. As Ayoade puts it (1991, p. 2), "climate is a generalization, while weather deals with specific events". However, climate should not be taken solely to be the average behavior of climate elements, but should also include its variations, a dynamic concept, as clearly described in the work of Monteiro (1976).

The urban climate "is a system that covers the climate of a given terrestrial space and its urbanization" (Monteiro; Mendonça, 2003 , p. 19). Depending on the discipline involved and the aims of the investigation, urban climates may cover areas of various sizes and numerous variables. The reference point adopted here concerns the diverse behavior of a set of climate elements divided up spatially according to their urban character, which may be single or multiple, depending on natural and anthropogenic climate factors.

The formation of urban climates is a fundamental topic for studies of environmental comfort in the fields of architecture and urbanism. Considering the case of heat comfort alone, the main reference parameter - temperature - is influenced by natural and anthropogenic climate factors and also by variation in other climate elements, such as precipitation, relative air humidity and the speed and direction of the wind. 
Anthropogenic climate factors include building volumes, ground surface, urban layout and human activities. These factors can modify the regional characteristics of the climate, on a variety of scales, forming urban mesoclimates and microclimates - local variations in the behavior of climate elements. One of the main results of these local changes is the accumulation of heat.

Various authors have examined this subject in depth, conducting bibliographical and documentary research, as well as field studies, involving direct observation and measurement of climate and environmental variables at various times of the year and detailed analyses showing the increase in temperature in urban settings. These authors include Monteiro (1976), Landsberg (1981), Lombardo (1985), Mascaró (1996), Tarifa \& Azevedo (2001), Freitas (2008) and Azerêdo (2017).

The capital of the State of Pernambuco is the object of study of this research. Its location between the Tropics of Cancer and Capricorn, at latitude $8^{\circ} 23^{\prime} \mathrm{S}$, situates the city in the torrid zone of the planet, where the climate is tropical. Being on the Eastern Atlantic coast of Brazil, exposed to predominantly southeasterly trade winds, the climate is coastal in nature. More specifically, the region surrounding Recife can be described as having a hot, humid coastal tropical climate, characterized principally by high temperatures throughout the year and high relative air humidity, of around $80 \%$, which helps to produce a reduced temperature range, by mitigating extreme temperatures. This lowers the maximum and increases the minimum temperatures, keeping the annual average at around $26^{\circ} \mathrm{C}$, considered mild, especially when exposed to constant moderate winds, of around $3 \mathrm{~m} / \mathrm{s}$, according to the Climate Norms for the 1981-2010 period published by the National Meteorological Institute/Inmet.

Supposing that, at a given time, atmospheric conditions are moderate, in a non-urbanized almost natural area, in the Curado neighborhood, for example, the weather station situated in this neighborhood may register a temperature of $25.5^{\circ} \mathrm{C}$. This corresponds to characteristic regional means for the hot, humid coastal tropical climate of Recife, according to the Inmet. In other parts of the city, the air temperature will not be the same. In general, it will be slightly higher. Various studies conducted by the Environmental Comfort Laboratory - Lacam, of the Federal University of Pernambuco UFPE, specifically identifying the microclimatic diversity at distinct locations by measuring climate variables, have revealed the possibility that heat accumulation may amount to as much as $6^{\circ} \mathrm{C}$ in Recife.

In the case of analysis or studies proposing interventions in certain parts of the city, in different stages of urbanization, the exclusive use of data collected in locations with the characteristics of a natural environment, such as weather stations, does not accurately reflect the behavior of climate elements in a highly urbanized setting, because of the obvious differences in use, occupation, urban geometry and materials between the two areas.

As there is no network of stations that could be used to measure air temperature and as it is hard to provide periodical 
systematic batches of measurements for each neighborhood or part of the city, a methodology needs to be developed that provides an estimate of the temperature readings for each specific area for nonscientific purposes. Identification of the type of area throughout the city and of the main features of the climate and of the urban morphology could provide an estimate of the maximum temperature for each locality, relating the level of urbanization to degree of heat accumulation.

The aim of this study is to present a methodology developed to estimate the maximum air temperature in a given urban locality (squares, plazas, crossroads, stretches of road or avenue), based on ten climatic factors.

Taking as the point of reference the air temperature registered at the weather station, it can be assumed that an environment with the same natural and morphological characteristics will have a similar air temperature. However, another environment, exposed to different local climatic factors with different morphological characteristics, will have a different air temperature, owing to heat accumulation.

The following concepts were outlined:

1) Temperature - is one of the central concepts of thermodynamics and one of the seven base units of the International System (IS), measured using a thermometer. "Every body has a property called temperature. When two bodies are in thermal equilibrium, their temperatures are equal" (Halliday, Resnick \& Walker, 2012, pp. 184-185).
2) Air temperature - "measures the perceptible heat stored in it and is commonly given in degrees Celsius or Fahrenheit and measured using a thermometer" (Mendonça \& Danni-Oliveira, 2009, p. 49). Considered a climate element, it is often used characterize a certain locality, using an instantaneous measurement or daily, monthly or annual means. Air temperature varies in time and space according to natural and anthropogenic, local and global climatic factors.

3) Heat - "variations in temperature are due to a change in the thermal energy of a system caused by the exchange of energy between the system and its surroundings [...] The energy transferred is called heat". In other words, heat "is the energy exchanged between a system and its surroundings owing to the difference in temperature". The greater the difference in temperature, the greater the quantity of energy exchanged between the media in question, until thermal equilibrium is established. As heat is a transferred energy, its unit of measurement in the International System is the joule (J), according to Halliday, Resnick \& Walker (2012, pp. 191-193).

4) Heat accumulation - in the case of heat accumulation, specifically, the reference temperature measured Inmet weather stations (automatic and conventional) is essential. When evaluating the environment using the ten climatic factors and measuring the number of degrees Celsius $\left({ }^{\circ} \mathrm{C}\right)$ heat accumulation, this figure is added to the maximum air temperature recorded by the weather station, to give the estimated 
temperature for the environment under study. In an urban environment, therefore, heat accumulation is nothing more than the difference in temperature in degrees Celsius $\left({ }^{\circ} \mathrm{C}\right)$, between the two environments, one of which is the weather station, in the case of the present article.

The proposal, therefore, is to build a heat accumulation scale of one to five: negative, zero, low, medium and high, as shown in Table 1. These are estimates based on the potential accumulation caused by each factor.

The estimated radius of influence here is 25 meters, which is the benchmark for characterization of climate elements at a weather station or an urban locality. This radius, however, may vary, up or down, depending on conditions in the immediate surroundings, be it the presence of natural elements (bodies of water, masses of vegetation, topographical variations), or changes in the urban form and that of built elements (urban geometry, building volumes, road systems, and human activities).

Analysis of any urban locality should consider various climatic factors that contribute separately to the estimated heat accumulation, depending on the intensity of socio-spatial and environmental transformations and the way the climate elements influence it.

Table 1 - Influence of each climate factor on heat accumulation in urban settings

\begin{tabular}{|c|c|}
\hline $\begin{array}{l}\text { Level of influence of climatic factors on air temperature behavior, } \\
\text { affecting heat accumulation, in urban settings }\end{array}$ & $\begin{array}{l}\text { Estimated heat } \\
\text { accumulation }\left({ }^{\circ} \mathrm{C}\right) \text { for each } \\
\text { local climate factor }\end{array}$ \\
\hline $\begin{array}{l}\text { Level One: a factor causes a reduction in air temperature, making conditions more like } \\
\text { a natural setting than those found at the weather station. }\end{array}$ & $-0,25$ \\
\hline $\begin{array}{l}\text { Level Two: a factor does not affect air temperature, meaning that the locality is } \\
\text { subject to low-intensity human intervention, with characteristics similar to a natural } \\
\text { environment. }\end{array}$ & 0 \\
\hline $\begin{array}{l}\text { Level Three: a factor causes a slight increase in air temperature, meaning that the } \\
\text { setting is subject to human intervention, and its characteristics differ from those of a } \\
\text { natural environment. }\end{array}$ & $+0,25$ \\
\hline $\begin{array}{l}\text { Level Four: a factor causes an increase in air temperature, due to significant variation } \\
\text { in the behavior of climate elements and/or the configuration of morphological } \\
\text { elements. }\end{array}$ & $+0,50$ \\
\hline $\begin{array}{l}\text { Level Five: a factor causes a large increase in air temperature, due to intensive } \\
\text { anthropic intervention, with total loss of natural elements. }\end{array}$ & $+0,75$ \\
\hline
\end{tabular}

Source: Ruskin Freitas. 
Table 2 - Levels of heat accumulation according to ten local climate factors

\begin{tabular}{|c|c|}
\hline $\begin{array}{c}\text { Behavior of temperature, affecting heat } \\
\text { accumulation in urban localities }\end{array}$ & $\begin{array}{c}\text { Estimated heat accumulation }\left({ }^{\circ} \mathrm{C}\right) \\
\text { caused by ten local climatic factors }\end{array}$ \\
\hline Negative & $-1,5$ to $-0,25$ \\
\hline Zero & 0 \\
\hline Low & 0,25 to 1,5 \\
\hline Medium & 1,75 to 3,5 \\
\hline High & 3,75 to 6,0 \\
\hline
\end{tabular}

Source: Ruskin Freitas.

These factors are here reduced to the following ten: elevation, maritimity, density of arboreal vegetation, wind permeability, ground surface permeability, sunlight exposure, built-up density, uses and road system, construction materials, and volumetric dynamics. The figures for heat accumulation for each of these factors (ranging from - 0.5 to $+0.75^{\circ} \mathrm{C}$ ) give a maximum total of $+6.0^{\circ} \mathrm{C}$, in relation to the weather station's maximum daily temperature.

Final characterization and classification of an urban locality should be based on the sum of the heat accumulation values for each one of the ten factors. The final sum can also be placed on a five-point scale, in relation to the sum of values for all ten factors, and may register as negative, zero, low, medium or high heat accumulation, as shown in Table 2.
This methodology is based on direct quantitative checklist-type evaluation for each value. However, it is recommended that it be accompanied by a more detailed qualitative analysis, taking into consideration the reciprocal influences of the various factors.

These figures are based on the fact that, in Recife, research carried out since 1997 has not found the heat accumulation in urban localities to exceed $6^{\circ} \mathrm{C}$. These studies were carried out in neighborhoods such as Várzea, Casa Amarela, Encruzilhada, Água Fria, Boa Vista, Espinheiro, and others (Freitas, 2008; Barros \& Lombardo, 2013; Freitas \& Azerêdo, 2014; França et al., 2015; Azerêdo, 2017; Moreira et al., 2017).

Below, we outline the ten climatic factors used in the study. 


\section{Elevation}

Elevation is a vertical distance, measured in meters, between a certain point on the surface of the earth and the level of the sea. On a local scale, this natural climate factor is often referred to as topography, expanding the concept and the approach beyond height, and also as 'description of the locality', topographical variations and their effects on climate elements, including other climatic factors.

Elevation exerts an influence on atmospheric pressure, exposure to solar radiation and wind, temperature, humidity and precipitation. In particular, elevation has an inversely proportional affect on temperature. This is due to decreased air density in higher layers of the atmosphere and also to the fact that the surface of the earth emits heat, which has previously been absorbed directly or through reflection, raising the heat nearer the surface.

On average, for every 100 meters of elevation, the air temperature falls $0.6^{\circ} \mathrm{C}$ (Ayoade, 1991, p. 53), and may fall as much as $1.0^{\circ} \mathrm{C}$, depending on the gradient, the orientation, the degree of exposure to sunlight and to ventilation and to the type of ground surface cover. Hills, therefore, have temperatures slightly lower than the plains. The appropriation of the relief in urban environmental design is a fact to be appreciated, changing from one location to another and at different times of the day. For instance, during the day, lowlying areas, located in a valley basin, may be shaded, while higher elevation areas are more exposed to the sun, but, at night, the opposite may occur, "the lower parts of valleys become warmer and drier than higher elevation areas, which remain better ventilated due to the circulation of the winds" (Schutzer, 2012, p. 84).

Given that Recife's weather station is located at an approximate elevation of only 10 meters, all the areas located at the same level and up to 20 meters have neutral heat accumulation of around $0^{\circ} \mathrm{C}$. The locations with elevations between 20 and 80 meters, in Recife, are located on the surrounding arc of hills, to the north, west and southwest. Most of these areas are densely occupied by low-income settlements, with little in the way of vegetation or open spaces. Above all, hill tops and slopes to the east and southeast, exposed to the dominant winds, have a slightly lower air temperature, of around $0.25^{\circ} \mathrm{C}$.

Elevations above 80 meters are rare and are mostly found in the far northwest of the city, in the Guabiraba neighborhood, which is also sparsely populated with dense tree cover. In these remote locations, the elevation lowers the air temperature by about $0.5^{\circ} \mathrm{C}$.

\section{Maritimity}

The term maritimity is used for a global climate factor that refers to the influence of the seas and oceans on climate elements, as opposed to continental masses. By analogy, this term is also applied to a local climate factor, to refer to the influence not only of oceans, but also lakes, reservoirs and all large masses of water, primarily on the temperature of the air and relative air humidity. 
Materials have specific heat properties, such as reflection or absorption. One of these properties is specific heat. For Ferraro \& Soares (1998, p. 283), "specific heat can be understood as a numerical measure of the quantity of heat that causes one unit of variation in temperature on one unit of mass of substance". In other words, it is the quantity of heat that is capable of causing one gram of a given material to increase in temperature by $1^{\circ} \mathrm{C}$.

As the specific heat of water is higher than most types of soil, much more heat and more time is needed to increase the temperature of aquatic surfaces than that of paved surfaces. Likewise, a longer period of time will have elapsed before accumulated heat is lost, causing significant differences in temperature between land and water. These differences in the temperature of materials cause differences in air temperature, atmospheric pressure and the production of wind, from areas of high pressure, with low air temperature, to areas of low pressure, with high temperatures. Locations closer to water masses have lower temperatures, lower temperature ranges, greater air humidity and higher wind velocity. Ribeiro, Braz \& Silva $(2013$, p. 5) calculate that the direct influence of the sea in terms of reducing temperature occurs in strip of land up to 140 meters wide. This figure varies according to the volume of water and the predominant direction of winds. Carvalho $(2018$, p. 53) bases this calculation on the banks of bodies of water, as outlined in Law n. 12,651/2012, in Brazil's Forest Code.
Using various points of reference, it is estimated that the oceanic coast up to 100 meters inland and the banks of rivers and lakes up to 30 meters, are subject to the influence of the sea, thereby reducing air temperature by around $0.5^{\circ} \mathrm{C}$. Areas downwind of such water masses have an area of influence twice as wide, although with half the reduction in temperature, of around $0.25^{\circ} \mathrm{C}$. As Recife's weather station is situated one kilometer from the River Capibaribe and over $10 \mathrm{~km}$ from the Atlantic Ocean, this point receives little influence from water masses. Similarly located points will not see a drop in temperature caused by this factor.

\section{Density of arboreal vegetation}

Vegetation is composed of living beings and, as such, has a metabolism and consumes energy, which it derives from soil and sunlight. The use of this energy for internal processes decreases the role of radiation that would otherwise be transformed into heat and transferred to the environment. Vegetation is thus one of the factors that moderate air temperature, acting also on air humidity and the direction and velocity of winds.

The evapotranspiration, grass and the shade provided by trees are also ways in which vegetation lowers the temperature of surfaces and of the air.

Freitas $(2008$, p. 81$)$ notes the role of vegetation in the formation of microclimates characterized by a reduction in temperature. 
Parks, squares, gardens, empty lots, and the banks of rivers and canals, which are, in general, surrounded by buildings, stand out from their surroundings, behaving in terms of climate more like a forest, although they act only on smaller surfaces in their direct proximity. Their spatial configuration conveys the Idea of an island of amenities.

In the case of predominantly urban areas with a few public or private free spaces, composed of clumps of arboreal vegetation, such as parks, gardens or roadsides, there is a decrease in temperature. As Mascaró \& Mascaró put it (2002, p. 49), "under clumps of trees, air temperature is $3^{\circ} \mathrm{C}$ to $4^{\circ} \mathrm{C}$ lower than in areas exposed to sunlight". Azerêdo (2017, p. 429) have also noted the role vegetation plays in reducing air temperature in its immediate surroundings, examining certain species of tree and showing that the effect on temperature may extend as far as 90 meters downwind of a single tree. It is thus essential to examine the species of trees, their size, density of foliage, canopy volume, along with the speed and direction of predominant winds.

Natural environments, with a high density of arboreal vegetation, such as woods and forests, especially on the outskirts of cities, may help to produce temperatures lower than those recorded by weather stations.

Urban areas with arboreal vegetation, especially compact or linear masses of vegetation, with species with a dense canopy, may have no effect on heat accumulation. On the contrary, as trees are replaced by built structures, areas with arboreal vegetation, with dense canopy cover, but with the individual trees widely spaced out have low heat accumulation, of around $0.25^{\circ} \mathrm{C}$, while similar areas with widely spaced out trees and sparse canopy cover may experience medium heat accumulation, of around $0.5^{\circ} \mathrm{C}$. Areas devoid of tree cover will have high heat accumulation of around $0.75^{\circ} \mathrm{C}$.

\section{Wind permeability}

Winds have a fundamental effect on climate, because they help to disperse particles present in the atmosphere and to move heat around through convection. In the case of a hot, humid coastal tropical climate, wind is one of the main factors that reduce the high temperature and humidity, making the environment pleasant for users, both within individual structures and in the city as a whole. More attention should thus be paid to ventilation in urban planning.

In dealing with the ordering of cities, the dimensions and the format of public spaces - roads, avenues, parks and squares -, as well as their balanced distribution in the urban environment, affect permeability to the predominant winds, in terms of speed and direction. In combination with the geometry of the roadways, the characteristics of buildings and the existing arboreal vegetation may or may not provide ventilation. The shape, height, width and distance between buildings all determine the speed with which the air flows between built masses. Depending on the layout and shape of built volumes, these may pose barriers, provoke turbulence, or channel air, along with various 
other aerodynamic effects. The tendency to absorb and emit heat into the environment is exacerbated when the shape of the urban fabric does not allow the heat to dissipate. From the city as a whole to its center, the canyon shape also intensifies heat storage and may even form islands of heat, depending on various factors, according to studies that have identified this phenomenon in specific places and at specific times.

Spaces completely free of barriers, exposed to the winds, such as the seafront, hilltops and spaces with no buildings nearby, may possess negative heat accumulation, of up to $-0.25^{\circ} \mathrm{C}$. Urban settings that are permeable to the wind, such as river banks, hillsides facing the wind and open spaces with widely spaced buildings allow the air to flow around them and exhibit zero heat accumulation, very near zero $0^{\circ} \mathrm{C}$. Open urban spaces flanked by buildings, with some space between them, enabling the wind to flow through, with medium-sized clumps of arboreal vegetation and high and/or sparse canopies, are associated with low heat accumulation of around $0.25^{\circ} \mathrm{C}$. Urban settings with little space between built volumes and only a few individual trees with dense canopies, blocking the wind, may occasion average heat accumulation, close to $0.5^{\circ} \mathrm{C}$. Urban settings with single blocks or groups of blocks, forming barriers, with arboreal vegetation lining both sides of the road, with dense canopies forming tunnels blocking the wind flow and the dispersal of hot air, may experience high heat accumulation, close to $0.75^{\circ} \mathrm{C}$.

\section{Ground surface permeability}

The ground surface undergoes substantial alteration with urbanization, especially when permeable natural green surfaces are replaced by built structures surrounded by parking lots, roads and paved surfaces and, hence, impermeable spaces.

Soil sealing also modifies the natural drainage system, causing water to be distributed differently, both horizontally, between hydrographic basins, and vertically, redirecting rainwater, reducing evaporation and infiltration, deep or superficial, and increasing surface runoff. The water that falls as rain rapidly flows away off the surfaces of streets, avenues, forecourts, and even paved canals, while they flow more slowly over exposed or overgrown ground. The increased runoff causes the environment to dry more quickly, reducing humidity and evaporation and raising temperatures.

As Boussoualim observes (2002, p. 35), "in the city, there is much less evaporation. Most of the energy, which is not spent by evaporation, serves to heat up the lower layers of the atmosphere and raise air temperature". The paved surfaces are very hot and further increase the temperature of the air.

A ground surface is considered permeable when it allows the infiltration of water and replenishment of the water table. It thus remains moist for longer and helps to reduce the surface temperature of covering material and lowers the air temperature. When the permeable ground is covered with 
vegetation, the mitigating effect of the natural environment is heightened, as the metabolism of the plants uses some solar radiation as energy, thus reducing its emission into the surrounding area.

An urban setting with a predominantly natural ground surface thus has zero heat accumulation.

Paved areas made of porous materials, such as ceramic tiles or cobblestones, and also those that intersperse permeable and impermeable stretches, may have low heat accumulation of about $0.25^{\circ} \mathrm{C}$.

Partially paved areas and those paved with impermeable materials but interspersed with some permeable stretches and/or porous materials, have average heat accumulation of $0.50^{\circ} \mathrm{C}$.

Areas that are fully paved with impermeable materials, especially materials with low specific heat and a high emissivity coefficient, such as concrete and asphalt, have high heat accumulation of about $0.75^{\circ} \mathrm{C}$.

\section{Exposure to sunlight}

The sun is our main source of energy and one of the most important factors so far as heat accumulation is concerned. Direct sunlight helps to increase the temperature, wear out materials and produce glare, and may cause health problems. It is important to relate the factors examined in this study one another, especially this one, since both high exposure to sunlight and the absence of it can be harmful, from the point of view of climate, and, consequently, in relation to the salubriousness of spaces on the scale of the whole city and that of individual buildings.

The shape of the city, including road systems and built volumes, has a huge impact on this factor. The orientation, length and width of roads in the road layout create greater or lower exposure to sunlight, as does its relation to the height and distribution of building volumes.

Katzschner (2007, p. 9) sees this factor as one of the most important in creating urban climates and even in the creation of heat islands in cities. A higher quotient for the relation between distance and height will have a positive effect on heat and a negative effect on ventilation, in cold climates. On the other hand, in hot, humid climates, if the distance between buildings is greater than their height, there is a positive effect on ventilation and a negative one on temperature, which a phenomenon that is much welcomed by city-dwellers in such climates.

One way of viewing exposure to sunlight is to see it in terms of the proportion of the sky that is visible, which, according to Souza et al. (2010, p. 156), is a "non-dimensional parameter, also called a configuration factor or angular factor", which "indicates a geometrical relation between the earth and the sky and represents and estimates of the area of visible sky", from any given point, on a street, a square, and so forth. All physical barriers (buildings, vegetation, awnings and the like) should be registered.

Urban areas with a width smaller than the mean height of surrounding buildings, generates a visible sky factor lower than 
$30^{\circ}$, which, in combination with the shade provided by trees and awnings, yields very low exposure to sunlight and a heat accumulation close to $0^{\circ} \mathrm{C}$.

Urban settings with a width similar to the mean height of surrounding buildings generate an angular factor of between 30 and $60^{\circ}$. Depending on shade, this can lead to low exposure to sunlight and low heat accumulation of around $0.25^{\circ} \mathrm{C}$.

In the case of areas whose width is greater than the mean height of buildings, depending on shade, the visible sky factor lies between 60 and $90^{\circ}$, causing medium heat accumulation of around $0.5^{\circ} \mathrm{C}$. Finally, urban areas with width greater than the mean height of buildings, with no shade and an angular factor of $90^{\circ}$, generate high exposure to sunlight and high heat accumulation of around $0.75^{\circ} \mathrm{C}$.

\section{Built-up density}

Built-up density refers to the total area of existing constructions divided by a certain surface area. The urbanization process generally occurs in parallel with an increase in density of the built environment, which may be by way of juxtaposition, as in historic areas and low-income settlements, with buildings very close to one another, or by superimposition of a built area, as occurs in predominantly high-rise zones. These are the two main ways of increasing built-up density.

Increased urban density leads to a compact urban configuration, which has become one of the main principles of sustainability, optimizing use of space, because of the proximity of residents, jobs, services and facilities (Gauzin-Müller, 2011, p. 55). However, in a hot, humid tropical climate, this environmental initiative should be considered with caution, as it has to be seen alongside other climatic factors, such as the need for natural ventilation to provide a comfortable and salubrious environment.

Increased built-up density is generally associated with land clearance and soil sealing, which help to raise the surface temperature and, thus, increase air temperature. When this density takes the form of very tightly packed buildings, with narrow streets, the urban areas produced are themselves confined and apt to store heat. When buildings are both close together and high-rise, the heat accumulation is compounded, since there is, at the same time, an increase in air temperature and a decrease in wind speed, which may also give rise to the formation of heat islands. Freitas (2008, p. 119) provides reflection and calculations regarding units of construction, the number of inhabitants in a given region, and the area in hectares, classifying them and relating population density to built-up density, based on the following classes.

In areas similar to the surroundings of the weather station up to a situation in which buildings are small and isolated, with a built area much smaller than the total land area, it can be said that heat accumulation is zero.

In an already consolidated urban area, with a population density of up to 72 people/ ha and single-story buildings, set apart from one another, with some vacant lots, the heat accumulation is low, around $0.25^{\circ} \mathrm{C}$. 
In areas with increasing urban density, with most lots occupied and the process of high-rise development already underway, with a population density of between 72 people/ha and 144 people/ha and a built area similar to the total area, heat accumulation is around $0.5^{\circ} \mathrm{C}$.

Very dense areas, with population density of over 144 people/ha, almost no space between buildings, significant high-rise development and built-up density equal to twice the total land area, heat accumulation is considered to be high, at around $0.75^{\circ} \mathrm{C}$.

\section{Uses and road system}

'Uses' refers to the way urban land is used, especially its use for construction and the kind of activities that can be conducted. On the broadest scale, we can identify rural and urban uses. Land for rural use has a large quantity of permeable ground surface and low building density, and low circulation of people and vehicles, and generates less heat compared to urban use. In cities, the main uses are housing, commerce and industry, all of which generate a certain flow of human beings, goods and services, whose production and circulation affect the climate, mainly by warming the environment. Intensive energy consumption in buildings (caused for example, by lighting and air conditioning), transport systems (which consume energy derived primarily from oil), industrial activity, commerce, services, and human waste all contribute to the formation and consolidation of the urban climate.

The road system hierarchy is characterized by the size of the roadways (length and width), the number of lanes, and the intensity of circulation, and is also directly related to the density of vegetation, ground surface permeability, and other uses and activities. Recife's Master Plan - Law $17,511 / 2008$, for example, classifies roads as local, collector and arterial.

Local roads are found, primarily, in residential zones, with mostly single-family residences, and low circulation of people and vehicles. In general, these are dirt tracks or cobbled, with a large amount of vegetation. Heat accumulation is thus near zero and the local temperature is preserved.

Collector roads are generally for mixed use, with residences, stores and services, increasing the flow of people and vehicles. The land surface is waterproofed, but still possesses some tree cover. These tend to be the main roads of a neighborhood and normally have low heat accumulation of around $0.25^{\circ} \mathrm{C}$. Secondary arterial roads have intensive circulation of people and vehicles and are situated in a predominantly commercial area. They combine high built-up density with low density of vegetation and generally connect different neighborhoods in the same city. They therefore exhibit medium heat accumulation of around $0.5^{\circ} \mathrm{C}$. Main arterial roads are predominantly used for commerce and services, with large-scale facilities (such as hypermarkets and hospitals), a high throughput of people and even higher of vehicles, especially collective public transport. These combine an impermeable ground surface (asphalt or concrete) and high building density with very little vegetation. They are usually the main roads of the city and form connections to other zones and, in the case of metropolitan regions, other cities, and tend to have a high heat accumulation of around $0.75^{\circ} \mathrm{C}$. 


\section{Construction materials}

All materials exchange heat with their surroundings in accordance with the difference in temperature. Heat is transferred from 'warmer' materials to 'colder' ones, until the thermal equilibrium of the system is established. Heat exchange can occur in various ways, the main one being radiation, whereby a body emits heat energy, which can be absorbed by another body, even if there is empty space between them. Every material causes a certain degree of heat exchange, depending on its constitution, density, thickness, texture, and color (Frota; Schiffer, 1988, p. 31).

The discussion here confines itself to construction materials used to build or clad walls surrounding lots or the façades of buildings surrounding a certain area. Depending on the physical properties of reflection, transmission, absorption and emission, these materials, when heated by solar radiation and/or (direct or indirect) radiation from other bodies, may affect the temperature of urban environments. Construction materials thus play a role in the formation of urban microclimates.

Smooth dense materials, with high reflection and heat emission coefficients, such as concrete, granite and stone, and dark ones, such as asphalt, which absorb a large part of the radiation and reflect it back into the environment, as part of the heat exchange process, help to increase the temperature of urban settings. Porous more highly textured materials, such as certain kinds of ceramic tile, and elements with apertures and cavities, such as concrete latticework and vegetation, especially trees, help to lower the temperature in such environments.

Urban settings comprising low-rise buildings, with façades in brickwork or clad with ceramic tiles, set back from the road, with vegetation, hedges, railings and latticework, contribute little to heat accumulation, which may be close to $0^{\circ} \mathrm{C}$.

Urban settings with buildings of various heights, with brickwork or ceramic tile clad façades, set back from the road, with green or permeable walls, contribute little in the way of heat accumulation-around $0.25^{\circ} \mathrm{C}$.

Open spaces with buildings and walls made of various materials, absorbent or reflective, may be characterized by average emission of radiation, providing medium heat accumulation of around $0.5^{\circ} \mathrm{C}$.

Spaces surrounded by predominantly high-rise buildings, with high reflective walls, made of dense and dark materials, generate a high accumulation of heat in urban settings, of around $0.75^{\circ} \mathrm{C}$.

\section{Volumetric dynamics}

Built volumes constitute a major anthropogenic climate factor, because of the soil sealing of the ground they occupy and because of their interference in the surroundings. Because of the properties of their materials, they increase air temperature and reduce relative air humidity. According to their shape, width, length, height and position, they alter the direction and speed of winds, and produce aerodynamic effects. Volumes cast shadows that may fall on other 
buildings. A building may also cast a shadow on itself, depending on its volumetric dynamics, heating or cooling surfaces external to it and affecting heat accumulation in the area, owing to interplay of various possible reflections of heat energy from one façade to another and to the surrounding open spaces.

For the purposes of heat accumulation estimation, volumetric dynamics will be based on the various buildings that comprise a certain urban district. For example, façades can be smooth or coarse, with recesses and protrusions, which may serve as balconies, helping to provide shade for the façade itself.

Alternating sunlight and shade cause variations in temperature, which, in turn, help wind circulation and mitigate the environmental discomfort characteristic of our hot, humid coastal tropical climate. The volumetric dynamics can also create alternative living spaces, because of the apparent passage of the sun over the surface of the earth. These spaces may be comfortable or uncomfortable, depending on their exposure to sunlight (Romero, 2001, p. 88).

Urban settings shaped by buildings that are highly dynamic volumetrically, with recesses and protrusions, balconies, eaves, awnings, brise-soleils and/or marquees, do not greatly increase temperature. These may considered to generate very low heat accumulation of almost $0^{\circ} \mathrm{C}$. Settings shaped by buildings and walls characterized by a diversity of volumes and shapes, with a moderate quantity of recesses and protrusions, may be considered to emit low levels of radiation and cause low heat accumulation of approximately $0.25^{\circ} \mathrm{C}$. Urban settings shaped by buildings and walls characterized by a diversity of volumes and shapes with mostly flat surfaces exhibit average radiation emission, causing medium heat accumulation of up to $0.5^{\circ} \mathrm{C}$. Urban settings that are completely enclosed by buildings with no diversity of volumes or forms, with smooth façades and high reflective walls, characterized by high radiation emission produce high heat accumulation of around $0.75^{\circ} \mathrm{C}$.

The photographs of two distinct locations shown below more clearly illustrate these points. Figure 1 shows a location in the Linha do Tiro neighborhood, in the northern part of the City of Recife/PE, which has an elevation of around 40 meters, lies approximately $6 \mathrm{~km}$ from the Atlantic Ocean, has average tree coverage, is permeable to wind, with permeable ground surface, average exposure to sunlight, low built-up density, local roads for residential use, materials with medium reflective potential and a fairly dynamic volumetrics. All of this adds up to low heat accumulation.

Figure 2 shows an urban setting in the Boa Vista neighborhood, also in Recife/PE, with the following characteristics: low elevation, continentality, low density of tree cover, wind permeability, impermeable ground surface, medium exposure to sunlight, high built-up density, arterial road with mixed use, materials with intermediate reflectivity, poor volumetric dynamics. These characteristics generate high heat accumulation.

Figure 3 shows the municipality of Recife/ PE and its neighborhoods. The predominance of natural elements lowers heat accumulation in some urban settings, such as those located in Apipucos, Linha do Tiro, Curado, University Campus and on the Boa Viagem seafront. The 
Figure 1 - Linha do Tiro, Recife - PE

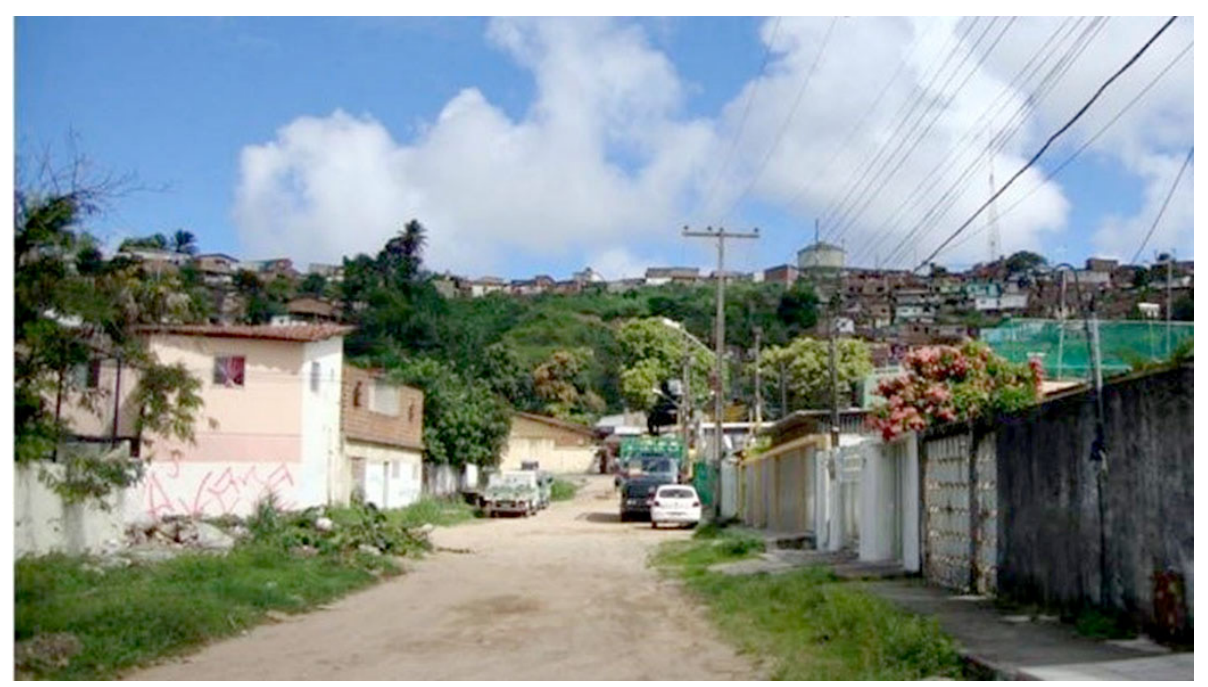

Source: Ruskin Freitas (2016).

Figure 2 - Boa Vista, Recife - PE

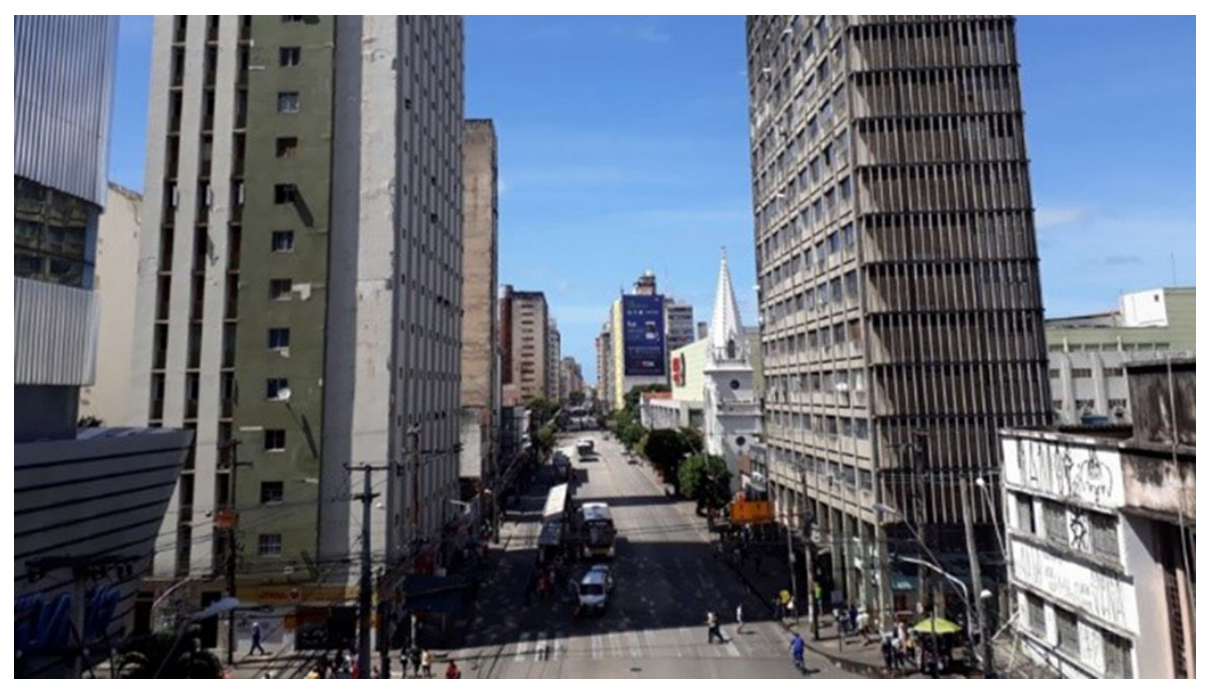

Source: Ruskin Freitas (2018). 
Table 3 - Examples of estimated heat accumulation $\left({ }^{\circ} \mathrm{C}\right)$ in urban localities

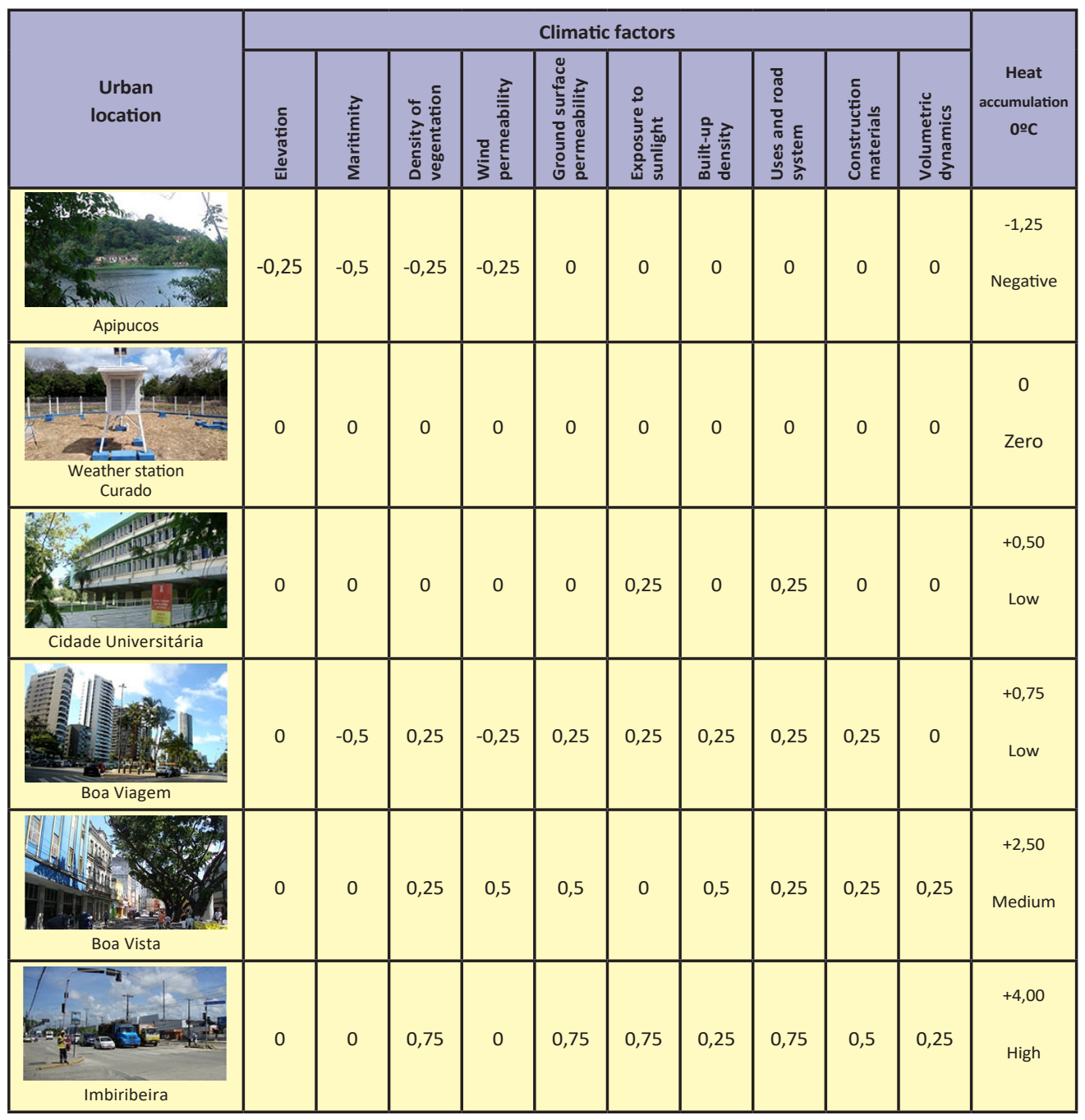

Source: Ruskin Freitas. 
Figure 3 - Recife - PE, showing the location mentioned in Figures 1 and 2 and Table 3

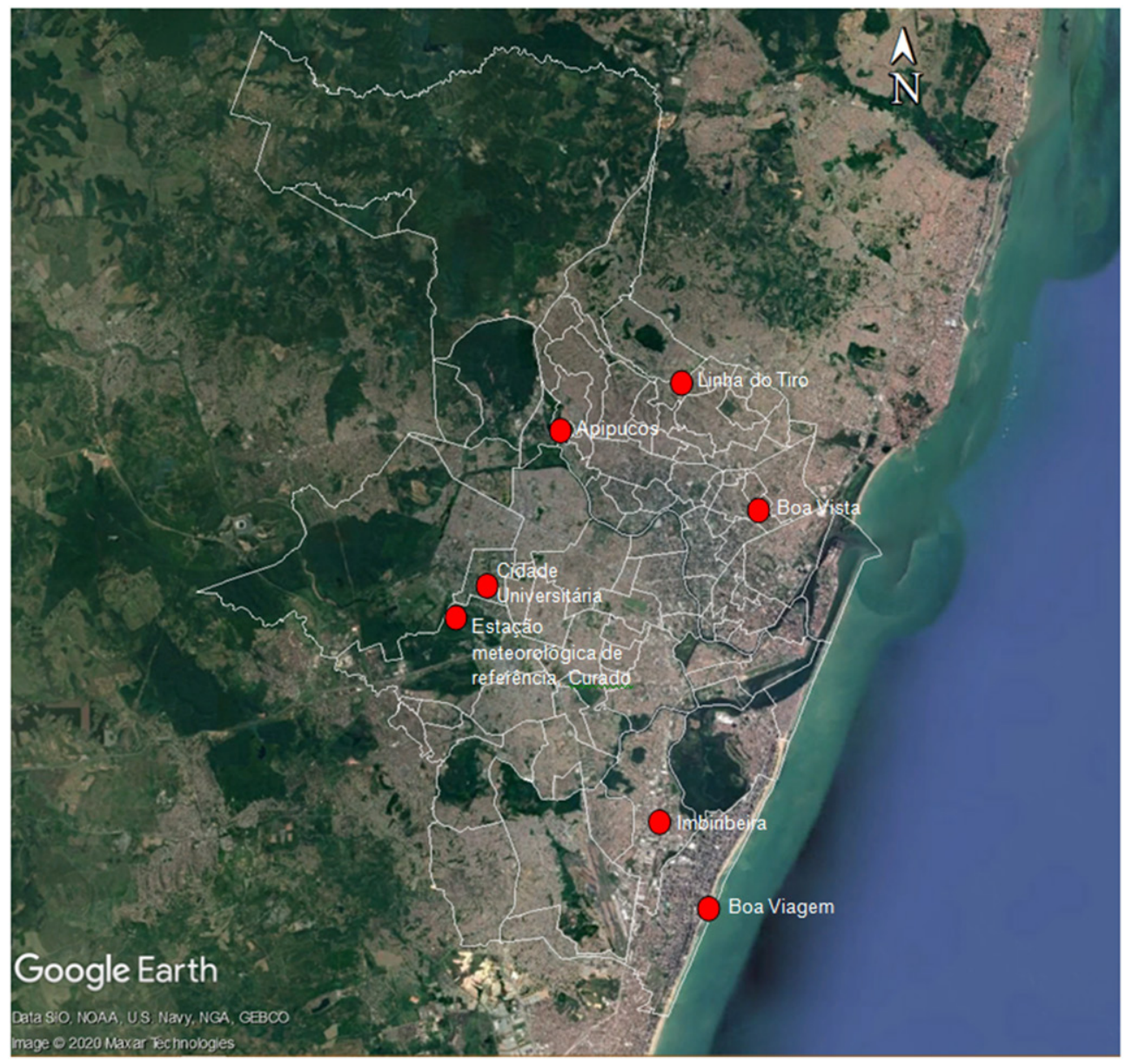

Source: Jaucele Azerêdo, based on images from Google Earth and Recife City Hall. Retrieved from http://dados. recife.pe.gov.br/dataset/area-urbana/resource/e43bee60-9448-4d3d-92ff-2378bc3b5b00, access in: 31 August 2020. 
predominance of built elements leads to high heat accumulation in other urban settings, such as those in Boa Vista and Imbiribeira.

\section{Concluding remarks}

Given the complexity of the urban climate system and the wide range of variables involved, studies of each space under analysis and/ or subject to intervention is of fundamental importance prior to any initial reports and/or proposals being drawn up. It should be noted that, because of the operational difficulties involved in any environmental characterization, it will not always be possible to make detailed systematic measurements of climate elements in urban settings.

One fairly viable way of producing a preliminary characterization of an area would be to visit the area and draw up a map of thermo-environmental comfort, using field research, observation and perceptions. This would involve providing a special representation of the sensation of heat, using colors (such as blue for relatively comfortable zones, red for uncomfortable zones and yellow for intermediate zones), according to the physical characteristics of the geographical area.

Another alternative would be to use measurements from a natural environment (such as those of a weather station) and observation of local, natural and human-made, climatic factors to estimate the temperature in an environment transformed by human beings, thereby characterizing a rich urban diversity, in terms both of morphology and of environment and climate. To this end, ten local climatic factors have been presented as points of reference, all of which are capable of altering heat accumulation in a certain urban setting. These are elevation, maritimity, density of arboreal vegetation, wind permeability, ground surface permeability, exposure to sunlight, built-up density, uses and road system, construction materials and volumetric dynamics.

The tactic was thus to develop a methodology for estimating the heat accumulation caused by the combined effect of these factors, as a way to improve knowledge of this subject and, moreover, assist urban planning. It should be noted that the variables and values outlined here are not the only ones, but these should provide a clear enough view for comparison of locations and surveying them prior to intervention.

The heat accumulation estimated for each factor was placed on a scale at intervals of $0.25^{\circ} \mathrm{C}$ and classified into five levels, from -0.5 to +0.75 , corresponding to negative, zero, low, medium and high heat accumulation.

Likewise, the final classification of any one location should take into account the sum of the heat accumulation values for each of ten factors. The final figure, between $-1.5^{\circ} \mathrm{C}$ and $+6^{\circ} \mathrm{C}$, can also be placed on the same fivepoint scale and compared with the maximum air temperature recorded at the Inmet weather station, which is used to represent the supposed regional temperature.

It is clear that this methodology could be subject to change. It is important, in a more indepth analysis, to relate various positive and negative heat accumulation factors, noting the way they interfere with and influence each other. Such an evaluation is no substitute 
for in-depth research and systematic measurement of atmospheric, structural and urban conditions, for the purposes of urban planning, building projects and improving the comfort of the environment. However, if a preliminary evaluation is needed, this evaluation will be extremely useful. Studies in this field have also been shown to be important for reviews of urban planning and building legislation, as such studies show the extent to which each element of an urban environment contributes to heat accumulation.

For example, if a certain area goes through an intensive period of urbanization, along with an increase in population density, high-rise development and soil sealing, there will probably be an increase in temperature and loss of environmental quality. With the application of the methodology presented here, it is possible to simulate scenarios and estimate the difference in temperature by estimating the heat accumulation before and after the proposed changes. This would cover factors such as increased levels of natural ground surface, reduced levels of occupation, and larger gaps between buildings.

Heat accumulation in urban spaces directly interferes with the quality of open spaces, both in terms of the comfort of the environment for users of internal spaces and for the interfaces between different systems. More in-depth and extensive investigation of these local climate changes may also help us to assess the contribution of these to climate changes at a global level.

If, in a city such as Recife, with a municipality of 1.7 million inhabitants and a Metropolitan Region of more than 4 million, there is a difference of up to $6^{\circ} \mathrm{C}$ between locations within this area, it should also be possible, by analogy, to calculate the heat accumulation for other localities, principally those of a metropolitan character, in which environmental, morphological and socioeconomic differences are exacerbated.

This methodology can be used by urban managers and technical staff, or even by students and ordinary citizens, to guide interventions that aim to improve user satisfaction, the efficiency of built space and environmental sustainability. The expectation is that other studies will be conducted both to consolidate the concepts developed here for a hot, humid coastal tropical climate and to develop others for different morphological and environmental contexts. 


\section{[I] https://orcid.org/0000-0001-7347-8302}

Universidade Federal de Pernambuco, curso de Arquitetura e Urbanismo, Programa de Pós-Graduação em Desenvolvimento Urbano. Recife, PE/Brasil.

ruskin37@uol.com.br

\section{[II] https://orcid.org/0000-0002-5853-8052}

Universidade Federal de Pernambuco, curso de Arquitetura e Urbanismo, Recife, PE/Brasil. jaucele_azeredo@hotmail.com

Translation: this article was translated by Peter Ratcliffe, peter@sharingenglish.com.br

\section{References}

ALMEIDA, E. M. A. (2019). A cidade como um sistema complexo: transformações morfológicas e climáticas em Maceió. Tese de doutorado. Maceió, Universidade Federal de Alagoas.

ALVIN, A. T. B.; KATO, V. R. C.; ROSSIN, J. R. G. (2015). A urgência das águas: intervenções urbanas em áreas de mananciais. Cadernos Metrópole. São Paulo, v. 17, n. 33, pp. 83-107.

AYOADE, J. O. (1991). Introdução à climatologia para os trópicos. Rio de Janeiro, Bertrand do Brasil.

AZERÊDO, J. F. F. A. (2017). Verde que te quero confortável: a contribuição da arborização urbana para o conforto termoambiental ao nível do usuário pedestre. Tese de doutorado. Recife, Universidade Federal de Pernambuco.

BARROS, H. R.; LOMBARDO, M. A. (2013). Zoneamento climático urbano da cidade do Recife: uma contribuição ao planejamento urbano. GEOUSP - espaço e tempo. São Paulo, n. 33, pp. 187-197.

BOUSSOUALIM, A. (2002). Contribuition à la caracterérisations de l'impact et de l'incidence du microclimat sur l'usage et les activités em espace public exterior-étude de cas à Blangnac. Thèse de doctorat. Nantes, École Polytechnique.

CARVALHO, L. T. (2018). Mapas climáticos: instrumentos para o planejamento urbano. Trabalho de Conclusão de Curso. Recife, Universidade Federal de Pernambuco.

FERRARO, N. G.; SOARES, P. A. T. (1998). Física básica. São Paulo, Atual.

FREITAS, R. (2008). Entre mitos e limites: as possibilidades do adensamento construtivo face à qualidade de vida no ambiente urbano. Recife, Editora Universitária da UFPE.

FREITAS, R.; AZERÊDO, J. (2014). A disciplina conforto ambiental: uma ferramenta prática na concepção de projetos de arquitetura, de urbanismo e de paisagismo. Cadernos Proarq. Rio de Janeiro, n. 20, pp. 94-113. 
FRANÇA, L. et al. (2015). “Análise do desconforto térmico causado pela ilha de calor urbana em um bairro do Recife-PE utilizando sensoriamento remoto". In: XVII SIMPÓSIO BRASILEIRO DE SENSORIAMENTO REMOTO. Anais... João Pessoa, INPE.

FROTA, A.; SCHIFFER, S. (1988). Manual de conforto térmico. São Paulo, Nobel.

GAUZIN-MÜLLER, D. (2011). Arquitetura ecológica. São Paulo, Senac.

INSTITUTO NACIONAL DE METEOROLOGIA. Normais climatológicas do Brasil 1981-2010. Disponível em: <http://www.inmet.gov.br/portal/index.php?r=clima/normaisClimatologicas>. Acesso em: 22 abr 2020.

HALLIDAY, D.; RESNICK, R; WALKER, J. (2012). Fundamentos de física: gravitação, ondas e termodinâmica. Rio de Janeiro, LTC.

KATZSCHNER, L. (2007). New developments in applied urban climatology. In: IX ENCONTRO NACIONAL E V ENCONTRO LATINO-AMERICANO DE CONFORTO NO AMBIENTE CONSTRUÍDO. Anais... Ouro Preto, Entac.

LANDSBERG, H. (1981). The urban climate. Nova York, Academic Press.

LOMBARDO, M. (1985). Ilha de calor nas metrópoles. São Paulo, Hucitec.

MASCARÓ, L.; MASCARÓ J. (2002). Vegetação urbana. Porto Alegre, Masquatro.

MASCARÓ, L. (coord.). (1996). Estudo da influência do adensamento da cidade de Porto Alegre na ventilação urbana. Porto Alegre, UFRGS.

MENDONÇA, F.; DANNI-OLIVEIRA, I. M. (2009). Climatologia: noções básicas de climas no Brasil. São Paulo, Oficina de Textos.

MONTEIRO, C. A. F.; MENDONÇA, F. (2003). Clima urbano. São Paulo, Contexto.

MONTEIRO, C. A. F. (1976). Teoria e clima urbano. Tese de livre-docência. São Paulo, Universidade de São Paulo.

MOREIRA, E. et al. (2017). O modelo sebal para estudos de clima intraurbano: aplicação em Recife, Pernambuco, Brasil. Revista Raega. Curitiba, v. 39, pp. 247-265.

OKE, T. et al. (2017). Urban Climates. Cambridge, Cambridge University Press.

PIRES, A. C. F.; KNEIB, E. C.; RIBEIRO, R. J. C. (2020). Impactos da metropolização no sistema de transporte coletivo: estudo de caso na Região Metropolitana de Goiânia. Cadernos Metrópole. São Paulo, v. 22, n. 47, pp. 247-272.

PREFEITURA MUNICIPAL DE RECIFE (2008). Lei n. 17.511/2008 - O Plano Diretor do Recife.

RIBEIRO, C. A. M.; BRAZ, A.; SILVA, F. (2013). Mapa de análises climáticas de João Pessoa - Paraíba. In: XII ENCONTRO NACIONAL E VIII ENCONTRO LATINO-AMERICANO DE CONFORTO NO AMBIENTE CONSTRUÍDO. Anais... Brasília, Antac.

ROMERO, M. (2001). Arquitetura bioclimática do espaço público. Brasília, UnB.

SCHUTZER, J. G. (2012). Cidade e meio ambiente: a apropriação do relevo no desenho ambiental urbano. São Paulo, Editora da Universidade de São Paulo. 
SOUZA, L. C. L. et al. (2010). Fator de visão do céu e intensidade de ilhas de calor na escala do pedestre - Sky view factor and urban heat islands intensity at the pedestrian level. Ambiente Construído. Porto Alegre, v. 10, n. 4, pp. 155-167.

STEWART, I. D.; OKE, T. R. (2012). Local climate zones for urban temperature studies. Disponível em: <http://journals.ametsoc.org/bams/article-pdf/93/12/1879/3739321/bams-d-11-00019_1. pdf>. Acesso em: 27 ago 2020.

TARIFA, J. R.; AZEVEDO, T. R. (2001). Os climas da cidade de São Paulo: teoria e prática. São Paulo, Geousp.

UNITED NATIONS, DEPARTMENT OF ECONOMIC AND SOCIAL AFFAIRS, POPULATION DIVISION (2017). World Population Prospects: the 2017 Revision, Key Findings and Advance Tables. Working Paper n. ESA/P/WP/248. Nova York, United Nations.

UNITED NATIONS, DEPARTMENT OF ECONOMIC AND SOCIAL AFFAIRS, POPULATION DIVISION (2019). World Urbanization Prospects: the 2018 Revision (ST/ESA/SER.A/420). Nova York, United Nations.

Received: May 4, 2020 Approved: October 8, 2020 